\title{
Phenolic Profiling and Antimicrobial Studies of Fagonia cretica native to Pakistan
}

\author{
Saima Naz ${ }^{1 *}$, Anum Khalid ${ }^{2}$ Surryia Manzoor ${ }^{2}$ \\ ${ }^{1 *}$ Division of Science and Technology, Department of Chemistry, University of Education Lahore, Multan Campus 60700 \\ Pakistan \\ ${ }^{2}$ Bahauddin Zakariya University Multan, Pakistan \\ *Corresponding Author's Email:saima.naz@ue.edu.pk
}

\begin{abstract}
The discovery of novel and more efficient antimicrobial agents from natural sources like plants is one of the most important ways through which the growing threat of antibiotic-resistant pathogens can be overcome. Herein, we report the potential antimicrobial activity and phenolic profiling of Fagonia cretica. Phenolic profiling was performed by using high-performance liquid chromatography (HPLC). Results showed major phenolic compounds were gallic acid, ferulic acid, cinnamic acid, catechin, and kaempferol in methanol, ethanol, and ethyl acetate fractions in various quantities comparatively others. The antimicrobial activity was analyzed using the disc diffusion method and determination of minimum inhibitory concentration; zones of inhibition and minimum extract concentration were used as indicators of antimicrobial activity. The maximum zones of inhibition $(\mathrm{mm})$ was found to be $23 \mathrm{~mm}$ of butanol fraction against E. coli, $27 \mathrm{~mm}$ of ethanol fraction against $P$. multocida, against S.aureus found to be $20 \mathrm{~mm}$ of ethanol fraction, against $B$. subtilus while it was $27 \mathrm{~mm}$ of butanol fraction respectively. Similarly against fungi i.e A. niger maximum zone of inhibition was found to be $21 \mathrm{~mm}$, in butanol fraction, against $A$.flavus, A. fusarium and $F$. soloni ethanol fraction showed $25 \mathrm{~mm}, 24 \mathrm{~mm}$, and $22 \mathrm{~mm}$ inhibition zone respectively. Similarly, minimum bactericidal and fungicidal concentrations were found to be of methanol, ethanol, and butanol fractions comparatively acetone, benzene, and ethyl acetate fractions of Fagonia cretica extracts. These results offer insights into the antimicrobial potency of this Pakistan local plant and provide a basis for further phytochemical and pharmacological research.
\end{abstract}

Keywords: Fagonia cretica extract; partition fractionation; antioxidant activity; antimicrobial activity; HPLC

\section{Highlights}

- Fagonia cretica, a Pakistan origin plant

- Analysis of the extract of Fagonia cretica using HPLC analytical technique

- Fagonia cretica contain highest amount Phenolic compounds in methanol solvent

- Fagonia cretica showed antimicrobial activities in different solvent

\section{Introduction}

In the world of the medical system, there is a great value to use medicinal plants for the benefits of living organisms (Yang et al., 2000). There are many therapeutic benefits for humans and all living things and recorded valuable information from all over the world (Corless et al., 2004). Throughout evolution progress, religious practices and rituals have the great charm for the treatment of disease and the benefits of plants. Substances that were used in earlier times are also utilized in modern times. Today, knowledge relating to the biological effects and biological synthesis of secondary plant metabolites has extended widely (Raskin et al., 2003).

Medicinal plants have active ingredients that produce an exact curing response in the treatment of living organisms. In older times, researchers idealized to use of synthetic medicines over natural medicines for curing processes. However, side effects relating to synthetic drugs for the treatment of various diseases are becoming widespread (Čižmárová, 2015). The natural products of all plants are chemically balanced and least harmful. There are many useful plants in the northern areas of Pakistan for the extraction of bioactive compounds (Ahmed, \& Gilani, 2009). The plant extract synthesis requires some suitable organic solvent. The extract of plant material and the essential oil is beneficial for human as well as animal health. The plant materials can be extracted either by classical or modern methods. Fractionation is a process of separation in which quantities of the mixture are subdivided in phase transition into a smaller number of fractions. The composition varies according to the gradient potential. The fractionation of samples involves the separation of major constituents that can be visualized and are useful in biomedical and biosynthesis. The medicinally important plants are fractionalized in order to 
have a complete analysis. The fractionation can be done by using an organic solvent, differential precipitation, or ultrafiltration.

The compounds related to phenols in plants are generally called phenolic compounds. They have an aromatic ring and a hydroxyl group. The chemical compounds are produced by plants to help them thrive from predators or pathogens. They are traditionally used in biomedical science. Quantitative assays demonstrate that there are many important vitamins and phytochemicals in plants such as phenolic compounds, alkaloids, lignin, saponins, and vitamins. Agents that kill microorganisms and stop their growth are usually categorized as antibiotics and antifungals which are used to kill bacteria and fungi. They can also have grouped based on their function i.e. Microbicidal or antimicrobial prophylaxis.

Fagonia cretica (F. cretica) plant is widely distributed in tropical, subtropical, and very warm areas of the world. It is usually presented in arid areas (Bainbridge et al., 2008). In Pakistan, it is usually present in D.G Khan, Multan, and surrounding areas. It is about $30 \mathrm{~cm}$ tall. Its leaves are opposite and rarely unifoliolate. Fagonia has a tap root, the main leaflet is glabrous, linear, and glandular to narrowly elliptic. Maybe petiole is present (Sterilized, 2000; Patil et al., 2008; Omale, \& Okafor, 2008). Fagonia is polypetalous, polysepalous and the flowers are stipulate, its petals are pink colored (Sheahan, \& Chase, 2000; Katewa, \& Galav, 2006). Qualitative phytochemical assays demonstrate the presence of saponins, coumarins, alkaloids, flavonoids, terpenoids, tannins, and sterols in polar and non-polar extracts. It is traditionally used in medicine (Qureshi et al., 2016). This is well-known for use in the treatment of various diseases of the vascular system of blood and the digestive system (Eman, 2011). Plants have received much attention as sources of biologically active substances and considered as richest source of natural antioxidant and antimicrobial agents that includes various medicinally important compounds i.e. polyphenols, carotenoids and flavonoids etc. The aims and objectives of current investigation was the search of phenolic compound of Fagonia cretica plants in several solvents using HPLC analysis for the isolation of compounds. The antibacterial and antifungal activities of the extract was detected through Disc diffusion method.

\section{Material and methods}

\subsection{Plant collection}

The plant material was selected based on their medicinal benefits and uses. Fresh parts of $F$. cretica were collected from Kabir wala district Khanewal in August 2017. The plant material was washed and completely dried. The materials were further legitimated and identified by Botanist, Dr. Zafar Ullah Zafar (Associate Professor), B.Z University, Multan, Pakistan.

\subsection{Extraction}

Aerial parts of $F$. cretica were rinsed with distilled water and cut into small pieces and dried under shade at room temperature completely ( $80 \mathrm{mesh}$ ). Extraction was carried out by using the method of Soxhlet extraction. $70 \mathrm{~g}$ of plant material was extracted with $500 \mathrm{ml}$ methanol for three hours in numerous batches. The extracts of the material were isolated from the residues by the process of filtration using filter paper. After this, the solvent was evaporated completely at the temperature of $45^{\circ} \mathrm{C}$ in a Rotary evaporator. The dried rudimentary extracts were then weighed to obtain and calculate the percentage yield and then stored at the temperature of $-4^{\circ} \mathrm{C}$ in a refrigerator and used for further analyses (Cho et al., 2010; Chaovanalikit \& Wrolstad 2004).

\subsection{Fractionation Procedure}

The crude methanolic extract of the plant (CME) was subjected to various biological analyses for pre-screening of potential biological and biomedical uses or activities. This methanolic extract $(20 \mathrm{~g})$ was then perched in $250 \mathrm{ml}$ of distilled water $\left(\mathrm{H}_{2} \mathrm{O}\right)$. This prepared suspension was then allowed to fractionation by solvent-solvent extraction, first with ethanol (EF) and then with butanol (BAF) by using a separating funnel (Pyrex, England). Three other fractions were obtained namely acetone fraction $(\mathrm{AF})$, benzene fraction $(\mathrm{BF})$, butanol $(\mathrm{BF})$, and aqueous fraction (AQF). All the fractions which were obtained dried and stored at $4^{\circ} \mathrm{C}$. These fractions were subjected to the antimicrobial and phytochemical assays (Cho et al., 2010)

\section{Antimicrobial Activity}




\subsubsection{Microbial strains}

Plant extracts were separately examined against microbes including, four species of fungi, and four species of bacteria. Four strains of fungi Aspergillus niger, Aspergillus flavus, Aspergillus fusarium, Fusarium solani, and four strains of bacteria Escherichia coli, Pasturella multocida, Staphylococcus aureus, Bacillus subtilis were used for testing of antimicrobial activity of $F$. cretica extract fractions

\subsubsection{Antimicrobial assay of Fagonia cretica fractions of extract}

Antimicrobial activity of the $F$. cretica extract fractions were screened against a panel of microorganisms, including four bacterial strains E. coli, P. multocida, B. subtilis, and S. aureus, and four fungal strains, A. Niger, A. flavus, A. fusarium F. Solani. Bacterial strains were cultured overnight at $37{ }^{\circ} \mathrm{C}$ in nutrient agar (Oxoid, UK) and fungal strains were cultured at $28^{\circ} \mathrm{C}$ for 48 hours using (PDA) potato dextrose agar (Oxoid, UK).

\subsubsection{Antimicrobial assay by disc diffusion method}

The antimicrobial activity of $F$. Cretica extract fractions was determined by using the disc diffusion method according to CLSI, 2007 16. Nutrient agar and potato dextrose agar were mixed and autoclaved, $100 \mu \mathrm{L} / 100 \mathrm{~mL}$ of the inocula was added in medium, then transferred in Petri plate and let to solidify. Small filter paper disks with $100 \mathrm{uL}$ sample were placed on it and incubated at $37^{\circ} \mathrm{C}$ and $28^{\circ} \mathrm{C}$ for 24 and 48 hours respectively. The diameters of inhibition zones were measured in millimeters with the help of a zone reader. The results were compared with the standard antimicrobial agent Rifampicin.

\subsubsection{Minimum Inhibitory Concentrations (MIC) of F. cretica extract fractions}

A single colony of bacteria was transferred into the broth and incubated. The broth was spun down using a centrifuge. The supernatant was discarded and the pellet was suspended using sterile normal saline and was centrifuged again until the pallet clear which was finally suspended in saline for further use. The optical density was recorded at $500 \mathrm{~nm}$. The optical density was in the range of 0.5-1.0. The dilution factor was calculated and carried out to obtain a concentration of $5 \times 10^{6} \mathrm{CFU} / \mathrm{mL}$ 17.

\subsubsection{Preparation of resazurin solution}

The resazurin solution was prepared by dissolving $270 \mathrm{mg}$ tablet in $40 \mathrm{~mL}$ of distilled water. $100 \mathrm{uL}$ of $F$. cretica of each solvent fraction were pipetted into the first row of a sterilized 96 well plate. To all other wells, $50 \mathrm{uL}$ of nutrient broth was added. Serial dilutions were performed such that each well had $50 \mathrm{uL}$ of the test material in serially descending order of concentration. To each well $10 \mathrm{uL}$ of resazurin indicator solution was added. Finally, $10 \mathrm{uL}$ of bacterial suspension $\left(5 \times 10^{6}\right.$ $\mathrm{CFU} / \mathrm{mL}$ ) was added to achieve a concentration of $5 \times 10^{5} \mathrm{CFU} / \mathrm{mL}$. The plates were then incubated at $37^{\circ} \mathrm{C}$ for bacteria for 12 hours. The absorbance was measured by micro quant at $500 \mathrm{~nm}$ for bacteria. The lowest concentration at which color changes occur was taken as MIC value

\subsection{Statistical Analysis}

The data was statistically analyzed (Steel, \& Torrie, 1960). Statistically significant differences $(\mathrm{p}<0.05)$ among means of experimental results were evaluated. The analysis of antimicrobial potential including the disc diffusion method and determination of minimum inhibitory concentration was based on three replications. The data obtained from three replications were reported as average \pm std. deviation (Steel \& Torrie 1960).

\section{Results and discussion}

\subsection{Percentage yield of fractions}

The extractive components in plants vary from season to season or the nature of solvents for the same plant. Plant bioactive components are mostly extracted by polar solvents where methanol is considered best in this regard. Fractionation yields of F. cretica represents that the polar solvents like methanol, ethanol, and acetone showed high extract yield $(2.6 \%, 3.0$ $\%, 2.76 \%)$, followed by less polar solvent fractions i.e. butanol $(2.58 \%)$ ethyl acetate $(1.94 \%)$, and benzene $(1.42 \%)$ 
respectively. The percentage yield is calculated by the formula while fractions with their percentage yield are given in Table 1.

\%age yield $=\frac{\text { obtained } \text { Weight }}{\text { Total } \text { Weight }} \times 100$

Table: 1

The percentage yield of various solvent fractions of extract of F. cretica

Sr. No

1
2
3
4
5
6

Solvent Fractions

$\begin{array}{cc}\text { Methanol } & 2.60 \% \\ \text { Ethanol } & 3 \% \\ \text { Ethyl acetate } & 1.94 \% \\ \text { Acetone } & 2.76 \% \\ \text { Butanol } & 2.58 \% \\ \text { Benzene } & 1.42 \%\end{array}$

Results reported in Table 1, showed that the \% age yield was maximum when ethanol was used and is minimum in the case of benzene fraction. The highest yield was obtained from ethanol fraction followed by Methanol>Acetone>Butanol $>$ Ethyl Acetate and Benzene. From the results, it was clear that the maximum yield was obtained in a polar solvent as compared to non-polar solvent fractions. The quantity of fractions collected depends upon the nature of the solvent, quantity of solvent, and shaking in the method of extraction (Fig. 1).

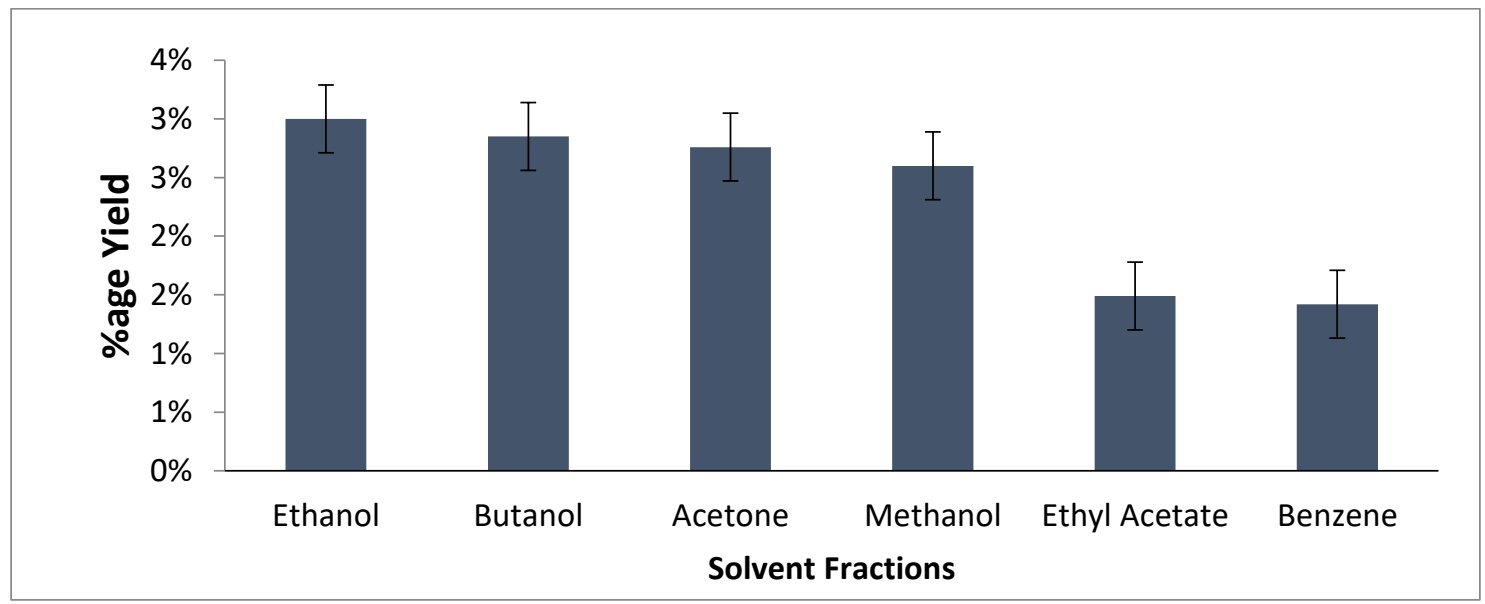

Fig. 1. The percentage yield of various solvent fractions of Fagonia cretica

It was observed by the researchers that amongst different fractions of fruit, the percent yield of $22.5 \%$ was obtained by hexane followed by ethyl acetate $21.3 \%$, n-butanol $19.2 \%$, aqueous $18.9 \%$, and chloroform $17.3 \%$. In the case of aerial parts, the highest percent yield was observed for n-butanol $32.5 \%$ followed by aqueous $28.5 \%$, ethyl acetate $22.5 \%$, hexane $8.5 \%$, and chloroform fraction $7.8 \%$. For roots, the highest percent yield $22.7 \%$ was calculated for hexane fraction followed by chloroform $22 \%$, aqueous $21.9 \%$, chloroform $17 \%$, and n-butanol $15.7 \%$.

\subsection{HPLC (High-Performance Liquid Chromatography) analysis}

The overall results regarding HPLC analysis of the plant extract and fractions is reported in Table 2. Results showed major phenolics are Gallic acid (170 in methanol,156 in ethanol, and 140.5 in ethyl acetate), Ferulic acid (135.5 in methanol, 122.8 
in ethanol,102.3 in ethyl acetate), cinnamic acid (140.2 in methanol, 132 in ethanol and 119 in ethyl acetate), catechin (229.9 in methanol, 201.1 in ethanol, 209.2 in ethyl acetate) and kaempferol (152.1 in methanol, 129.9 in ethanol and 112.2 in case of ethyl acetate). The minor components which were present in the extracts and residue were benzoic acid (52.7 in methanol, 44 in ethanol, and 35 in case of ethyl acetate), coumaric acid (60.8 in methanol,54 in ethanol, and 48 in ethyl acetate), caffeic acid 6.01 in methanol, 20.1 in ethanol and 5.6 in ethyl acetate. The Maximum concentration that was showed by catechin followed by ferulic acid> cinnamic acid > kaempferol> apigenin> salicylic acid> catechol> ellagic acid> hesperidin> chrysene> rutin > caffeic acid > benzoic acid in both extracts and fractional residue of $F$. cretica. The HPLC chromatogram of the extract of $F$. cretica in ethyl acetate, ethanol, and methanol presented in the Figures 2-4. Detail search reveal that the methanolic extracts of root of $F$. cretica contain highest phenolic content $(4.300 \pm 0.008) \mathrm{mg} / \mathrm{mL}$ GAE. In case of fruit, nbutanol fraction exhibited the highest value of $(3.20 \pm 0.02) \mathrm{mg} / \mathrm{mL}$ GAE while in case of aerial parts, aqueous fraction superseded the other fractions with a value of $(3.81 \pm 0.09) \mathrm{mg} / \mathrm{mL}$ GAE. The lowest TPC value $(0.230 \pm 0.008)$ was found for n-butanol fraction of the aerial parts of the plant (Cho et al., 2010).

\section{Table 2.}

HPLC analysis of Fagonia cretica Methanol extract, ethanol and ethyl acetate fraction

\begin{tabular}{cccccc}
\hline & No & Compound & Methanol & Ethanol & Ethyl acetate \\
& 1. & $\mu g$ g dry sample & & 156.1 & 140.5 \\
& 2. & Gallic acid & 170 & 97.4 & 76.2 \\
Phenolic Acids & 3. & Pyrogallol & 66.11 & 26.4 & 52.3 \\
& 4. & Vanillic acid & 29.03 & 17.1 & 36.2 \\
& 5. & Caffeic acid & 6.01 & 20.1 & 5.6 \\
& 6. & Ferulic acid & 135.3 & 122.8 & 102.3 \\
& 7. & Catechol & 92.4 & 80 & 59 \\
& 8. & Salicylic acid & 159.1 & 149 & 49 \\
& 9. & Elagic acid & 70.2 & 58 & 35 \\
& 10. & Benzoic acid & 52.7 & 44 & 48 \\
& 11. & Coumaric acid & 60.8 & 54 & 119 \\
& 12. & Cinamic acid & 140.2 & 132 & 51 \\
& 13 & Chrysin & 80.1 & 68 & 77.8 \\
& 14 & Hespiridin & 87.9 & 68.1 & 68.1 \\
& 15 & Apigenin & 108.9 & 89.2 & 162.3 \\
& 16 & Quercetin & 194 & 180.2 & 209.2 \\
17 & Catechin & 229.9 & 201.1 & 112.2 \\
& 18 & Kampferol & 152.1 & 129.9 & 29.8 \\
& 19 & Rutin & 70 & 51.4 & 116 \\
\hline
\end{tabular}




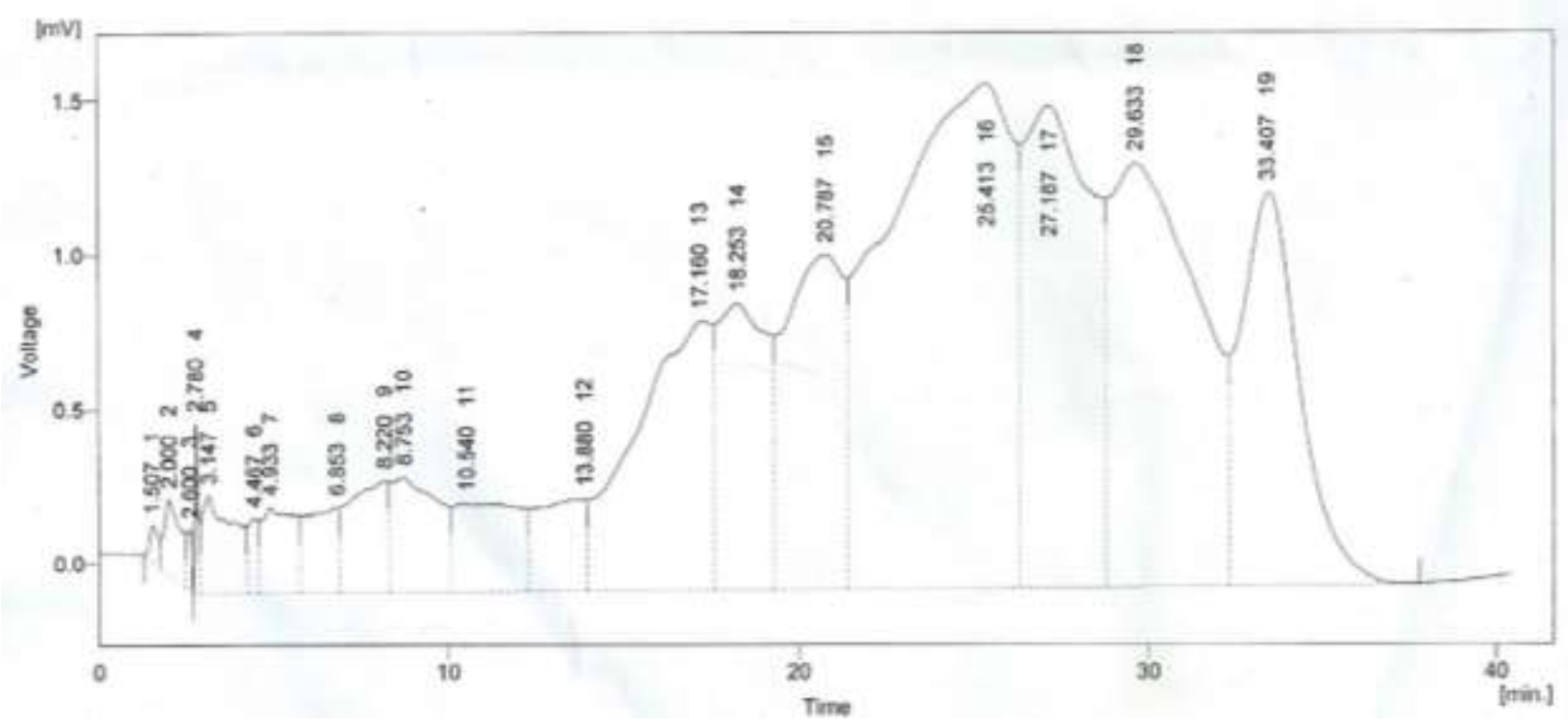

Fig. 2. HPLC chromatogram of ethyl acetate fraction of FagoniaCretica extract

\section{2 . Antimicrobial assays}

\subsubsection{Antibacterial activity by Disc diffusion method}

Antibacterial tests of $F$. cretica extracts and fractions carried were out by the disc diffusion method with little modification. The strains of bacteria used for testing were E. coli, P. multocida, S. aureus, and B. subtilus. The F. cretica solvent fraction was directly applied onto the bacterial strain and measured zone of inhibition given in Table ( $3 \& 4)$. The zones of inhibition (mm) against $E$. coli were found to be $17,21,15,10,13$ and $23 \mathrm{~mm}$ against $P$. multocida $2,5,27,31,18,12,18$ and $20 \mathrm{~mm}$, against S.aureusr found to be 18,20,15,11,14 and $19 \mathrm{~mm}$, against B. subtilus it were 25,27,31,18,22 and 27 mm for methanol, ethanol, acetone, benzene, ethyl acetate and butanol fractions respectively. Similarly, against fungi i.e A. niger zones of inhibition were found to 12,18,20,13,15 and $21 \mathrm{~mm}$ against $A$. flavus 23,25,19,16 and 15, against $A$. fusarium 21,24,20,13,11 and 28 and against $F$. soloni 20,22,18,15,13 and 25 for methanol, ethanol, acetone, benzene, ethyl acetate and butanol fractions respectively.

\section{Table 3}

Antibacterial activity of Methanol, Ethanol, and acetone fractions against various strains of bacteria

\begin{tabular}{ccccc}
\hline Microorganism & Methanol fraction & Ethanol fraction & Acetone fraction & Rifampicin \\
\hline E. coli & $17 \pm 0.01$ & $21 \pm 0.01$ & $15 \pm 0.02$ & $27 \pm 0.01$ \\
$\boldsymbol{P}$. multocida & $21 \pm 0.02$ & $23 \pm 0.02$ & $18 \pm 0.03$ & $30 \pm 0.01$ \\
B. subtilis & $25 \pm 0.01$ & $27 \pm 0.02$ & $31 \pm 0.04$ & $34 \pm 0.01$ \\
S. aureus & $18 \pm 0.03$ & $20 \pm 0.01$ & $15 \pm 0.03$ & $24 \pm 0.03$ \\
\hline
\end{tabular}

The data presented in Table is the mean of three independent experiments

\section{Table 4}

Antibacterial activity of Benzene, Ethyl acetate and butanol fractions against various strains of bacteria 


\begin{tabular}{ccccc}
\hline Microorganism & Benzene & Ethyl acetate & Butanol & Rifampicin \\
\hline E. coli & $10 \pm 0.01$ & $13 \pm 0.05$ & $23 \pm 0.04$ & $27 \pm 0.01$ \\
$\boldsymbol{P}$. multocida & $12 \pm 0.01$ & $18 \pm 0.02$ & $20 \pm 0.02$ & $30 \pm 0.01$ \\
B. subtilis & $18 \pm 0.01$ & $22 \pm 0.01$ & $27 \pm 0.02$ & $34 \pm 0.01$ \\
S. aureus & $11 \pm 0.01$ & $14 \pm 0.01$ & $19 \pm 0.01$ & $24 \pm 0.03$ \\
\hline
\end{tabular}

The data presented in the Table is the mean of three independent experiments

From the results given in Tables (3-4) it was concluded that in the case of E. coli measured inhibition zones were 17, $21,15,10,13$, and $23 \mathrm{~mm}$ for methanol, ethanol, acetone, benzene, ethyl acetate, and butanol fractions respectively. The positive control inhibitory zone was $27 \mathrm{~mm}$. Maximum inhibition zone was showed by butanol fraction followed by ethyl acetate<Acetone $<$ Methanol<Ethanol and $<$ Butanol. In the case of P. multicoda zone of inhibition was found to be $21,23,18,12,18$, and $20 \mathrm{~mm}$ for methanol, ethanol, acetone, benzene, ethyl acetate, and butanol fractions respectively. The positive control inhibitory zone was $30 \mathrm{~mm}$. The order of efficiency of plant extract can be given in ascending order; Benzene $<$ Acetone $<$ Ethyl acetate $<$ Methanol $<$ Ethanol $<$ Butanol. In the case of B.Subtils, the zone of inhibition comes out 25,27,31,18, 22, and $27 \mathrm{~mm}$ for methanol, ethanol, acetone, benzene, ethyl acetate, and butanol fractions respectively. The standard control gives a $34 \mathrm{~mm}$ zone of inhibition. The order of efficiency of plant extract fractions with solvent can be given as Benzene<Ethyl acetate<Methanol<Ethanol <Butanol. In the case of $S$. aureus, the zones come out $18,20,15,11,14,19$ for methanol, ethanol, acetone, benzene, ethyl acetate, and butanol fractions respectively. The standard positive control gives a $24 \mathrm{~mm}$ zone of inhibition. Benzene fraction showed maximum activity against $S$. aureus followed by Benzene $<$ Ethyl acetate $<$ Acetone $<$ Methanol $<$ Butanol $<$ Ethanol (Chaovanalikit \& Wrolstad 2004; Fritscheet al., 2007).

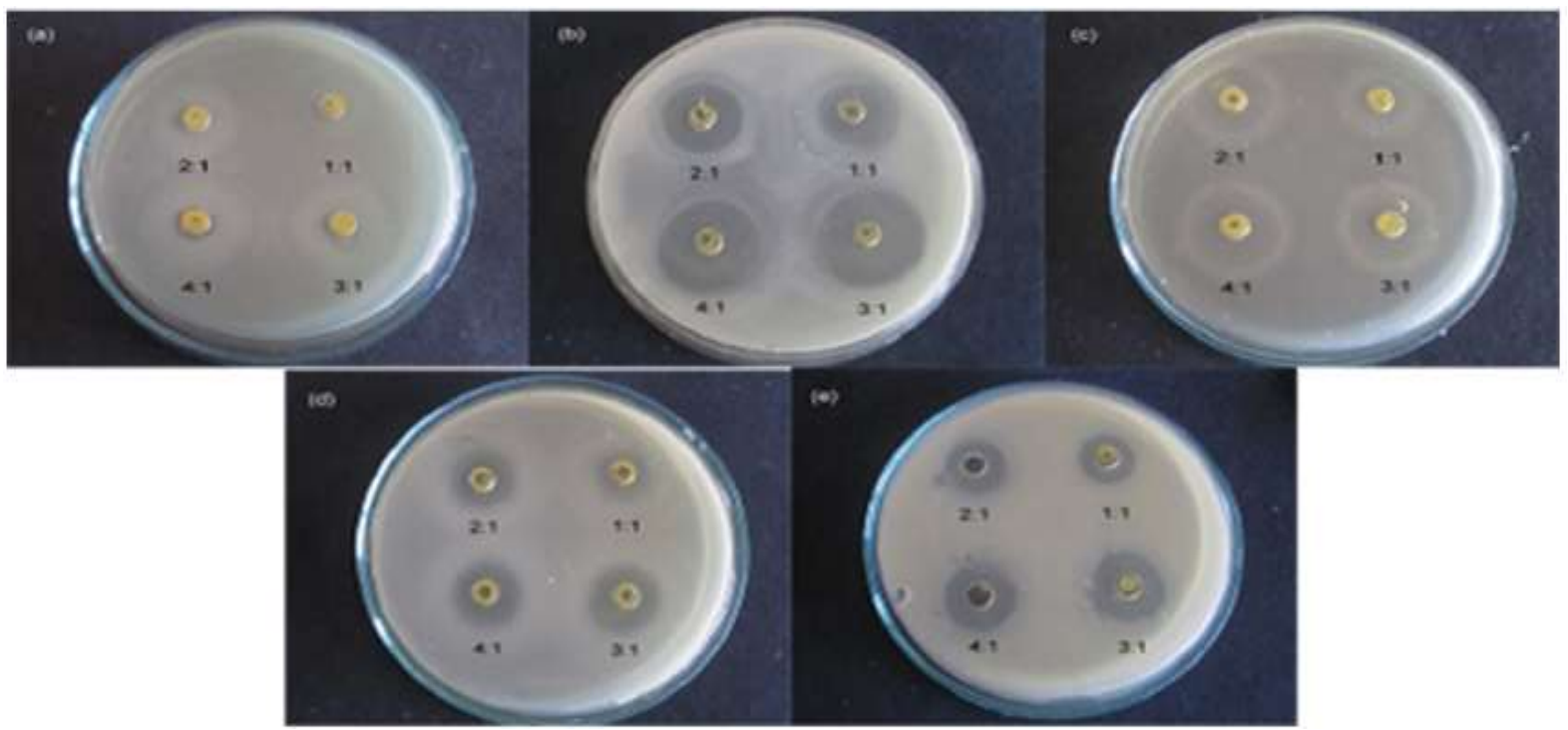

Fig. 3. Antibacterial activity of $F$. cretica extract fractions against $P$. multocida and B. subtilus 

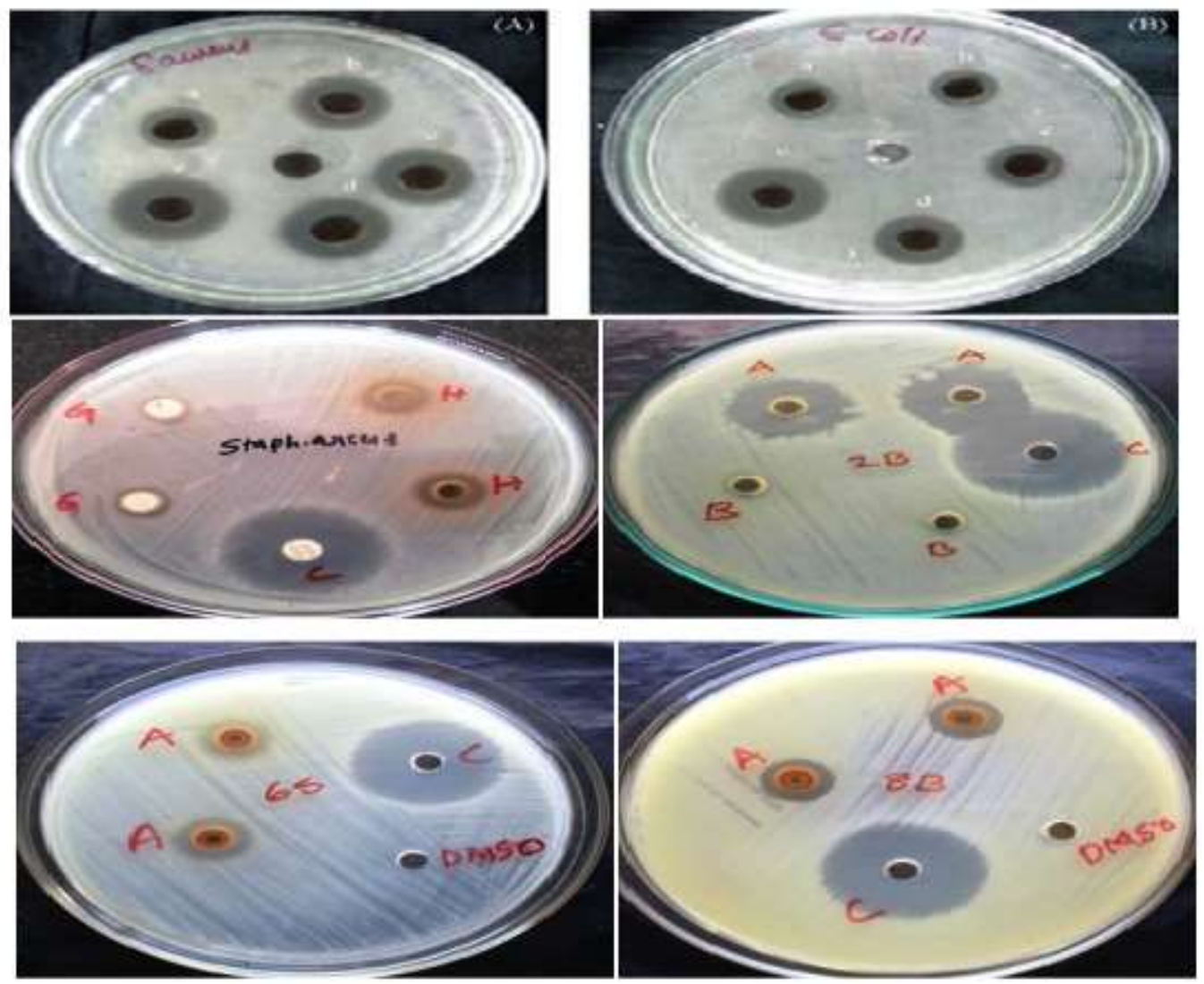

Fig. 4. Antibacterial activity of F. cretica extract fractions against E. coli and S. aureus

\subsubsection{Antifungal activity of the Fagonia cretica extracts}

Like antibacterial assay, the antifungal activity of $F$. cretica solvent extract fractions were also conducted with the same methodology where instead of bacterial strains fungal strain along with nutrient medium and standard control used. The plates were prepared and the results of various solvent fractions of $F$. cretica against microorganisms are reported in Table (5\&6).

\section{Table 5}

Antifungal activity of Methanol, Ethanol and acetone fractions against various strains of fungus

\begin{tabular}{ccccc}
\hline Fungal strain & $\begin{array}{c}\text { Methanol } \\
\text { fraction }\end{array}$ & Ethanol fraction & Acetone fraction & Fluconazole \\
\hline A. niger & $12 \pm 0.02$ & $18 \pm 0.01$ & $20 \pm 0.02$ & $24 \pm 0.03$ \\
A. flavus & $23 \pm 0.02$ & $25 \pm 0.02$ & $19 \pm 0.01$ & $29 \pm 0.01$ \\
A. fusarium & $21 \pm 0.01$ & $24 \pm 0.03$ & $20 \pm 0.03$ & $32 \pm 0.01$
\end{tabular}


$\begin{array}{lllll}\text { F. Solani } & 20 \pm 0.01 & 22 \pm 0.03 & 28 \pm 0.02 & 18 \pm 0.03\end{array}$

The data presented in the Table is the mean of three independent experiments.

Table 6

Antifungal activity of Benzene, Ethyl acetate, and butanol fractions against various strains of fungus

\begin{tabular}{ccccc}
\hline Microorganism & Benzene & Ethyl acetate & Butanol & Fluconazole \\
\hline A. niger & $13 \pm 0.02$ & $15 \pm 0.01$ & $21 \pm 0.02$ & $24 \pm 0.03$ \\
A. flavus & $16 \pm 0.01$ & $15 \pm 0.04$ & $26 \pm 0.01$ & $29 \pm 0.01$ \\
A. fusarium & $13 \pm 0.04$ & $11 \pm 0.01$ & $28 \pm 0.01$ & $32 \pm 0.01$ \\
F. Solani & $15 \pm 0.04$ & $13 \pm 0.02$ & $25 \pm 0.02$ & $28 \pm 0.02$ \\
\hline
\end{tabular}

\section{The data presented in Table is the mean of three independent experiments.}

From results given in Table (5-6) it was concluded that in the case of A. niger zone of inhibition found 12,18,20,13,15 and $21 \mathrm{~mm}$ for methanol, ethanol, acetone, benzene, ethyl acetate, and butanol fractions respectively. The positive control inhibition zone was $24 \mathrm{~mm}$. The order of efficiency of $F$. cretica extract fractions can be written as; Methanol<benzene<ethyl acetate<ethanol<acetone $<$ butanol
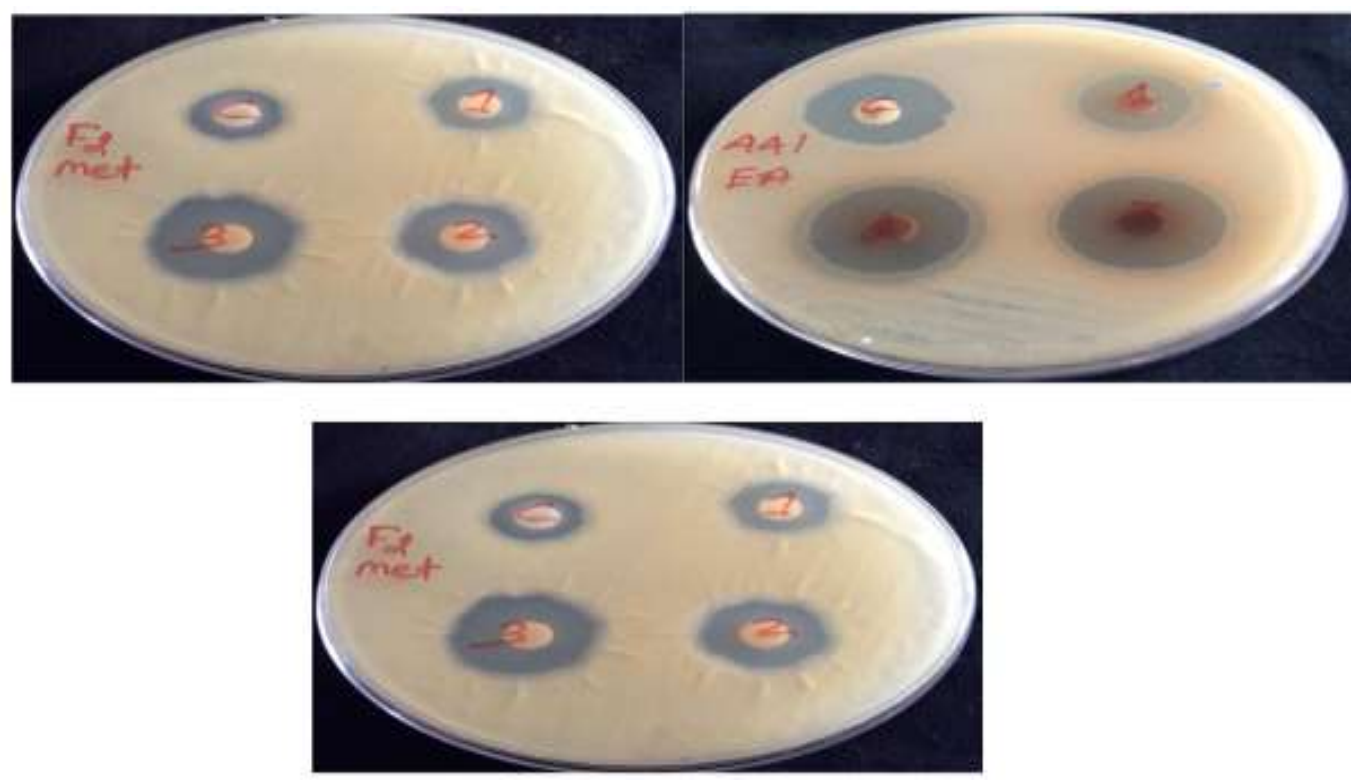

Fig. 4. Antifungal activity of $F$. cretica extract fractions against A.flavus

In the case of A. flavus zone of inhibition comes out to be $23,25,19,16,15$ and $26 \mathrm{~mm}$ for methanol, ethanol, acetone, benzene, ethyl acetate, and butanol fractions respectively. The inhibition zone showed by fluconazole was $29 \mathrm{~mm}$. The order of efficiency of plant extract fractions can be given as Ethyl Acetate $<$ Benzene $<$ Acetone $<$ Methanol $<$ Ethanol $<$ Butanol. 
Against A. fusarium observed zone of inhibition were21,24,20,13,11 and $28 \mathrm{~mm}$ produced by methanol, ethanol, acetone, benzene, ethyl acetate, and butanol fractions respectively. Ethyl acetate showed maximum fungal inhibitory potential followed by other fractions in order like Ethyl Acetate $<$ Benzene $<$ Acetone $<$ Methanol $<$ Ethanol $<$ Butanol. (Anjum et al., 2013; Cho et al., 2010).
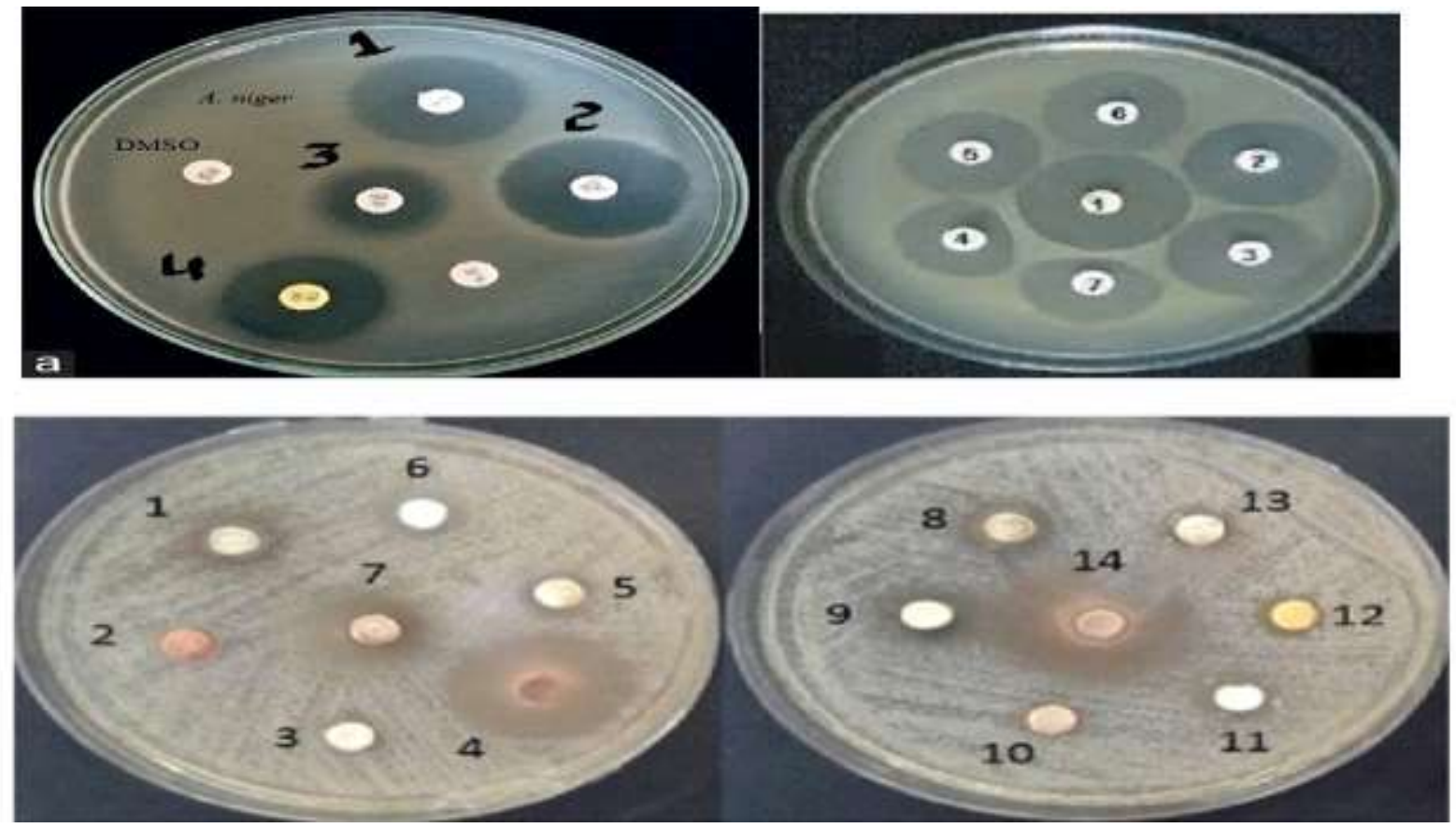

Fig. 5. Antifungal

activity of $F$. cretica extract fractions against $A$. niger and $F$.solani

Against F.soloni as shown in Table (5\&6) measured zones of inhibition were 20,22, 18,15,13, and 25 produced by methanol, ethanol, acetone, benzene, ethyl acetate, and butanol fractions respectively. Consequently, the order of efficiency of plant fractions against F.solani can be written as; Ethyl acetate<Benzene<Acetone <Methanol $<$ Ethanol $<$ Butanol (Fig.4\&6)

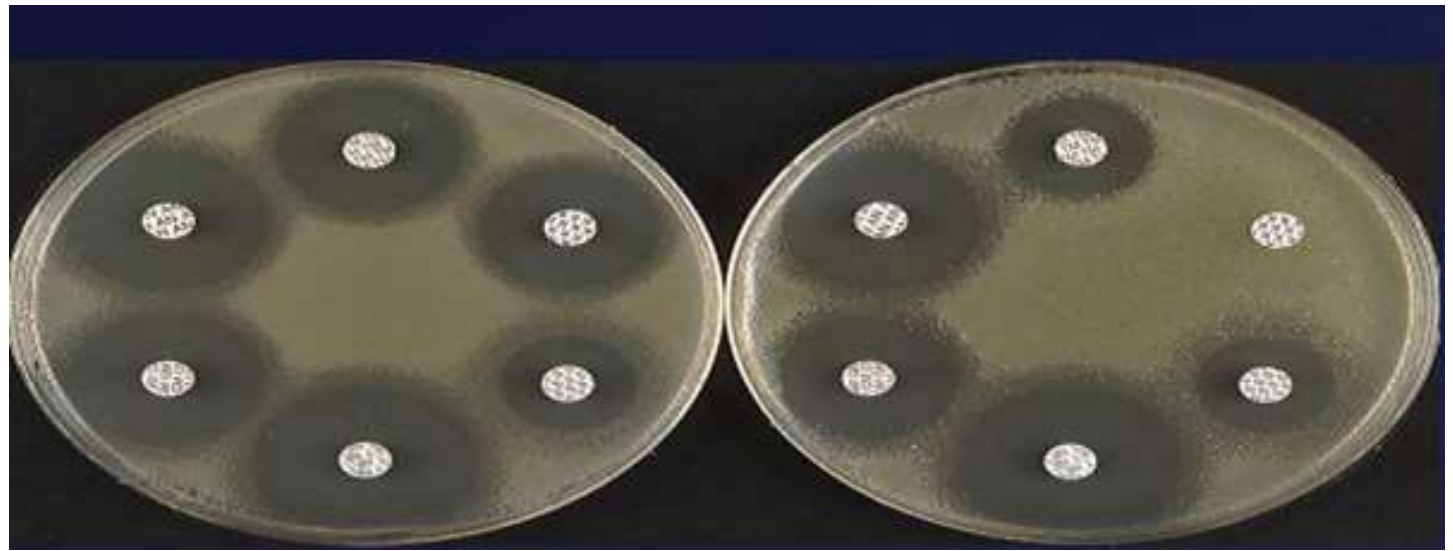

Fig. 6. Antifungal activity of $F$. cretica extract fractions against $A$. fusarium

\subsubsection{Determination of Minimum inhibitory concentration (MIC)}

The minimum amount of plant extract which can control the growth of microorganism is called a minimum inhibitory concentration method. It is the lowest concentration of active constituents that prevent the growth of bacteria and fungi. The 
activity depends upon the type of bacteria and fungi as well as the type of active chemicals or natural phytoconstituents (Cho et al., 2010).

\subsubsection{Minimum bactericidal concentration}

MIC in $\mu \mathrm{g} / \mathrm{ml}$ can be determined by preparing solutions of various concentrations or dilutions of solvent fractions. The results of minimum bactericidal concentration of various solvent fractions of $F$. cretica are given below in Tables (6\&7). It was shown in Tables (6\&7) that the minimum inhibitory concentrations against E.coli were found to be 1.92,2.13,2.07,2.07,2.39 and $2.06 \mu \mathrm{g} / \mathrm{ml}$ of methanol, ethanol, acetone, benzene, ethyl acetate, and butanol fractions respectively. The positive control concentration required to kill bacteria was found to be $3.8 \mu \mathrm{g} / \mathrm{mL}$. Minimum concentration of ethyl acetate can kill the bacterial strains more efficiently followed by other solvent fractions as Acetate $<$ Ethanol $<$ Acetone $<$ Benzene $<$ Butanol $<$ Methanol. The minimum inhibitory concentration zone against $p$. multocida strain comes out $1.83,2.33,2.54,2.21,2.29$, and $2.65 \mu \mathrm{g} / \mathrm{ml}$ of methanol, ethanol, acetone, benzene, ethyl acetate, and butanol fractions respectively. The positive control showed a minimum concentration of $3.97 \mu \mathrm{g} / \mathrm{ml}$. In conclusion, it can be said that butanol fraction extract showed minimum efficient active concentration to kill P. multocida strain followed by other fraction as Butanol $<$ Ethanol $<$ Acetone $<$ Ethyl acetate $<$ Benzene $<$ Methanol

Table 6

Minimum bactericidal concentration of $F$. cretica solvent fractions against selected bacterial strains

\begin{tabular}{ccccc}
\hline Bacterial strains & $\begin{array}{c}\text { Methanol fraction } \\
\boldsymbol{\mu g} / \mathbf{m l}\end{array}$ & $\begin{array}{c}\text { Ethanol fraction } \\
\boldsymbol{\mu g} / \mathbf{m l}\end{array}$ & $\begin{array}{c}\text { Acetone fraction } \\
\boldsymbol{\mu g} / \mathbf{m l}\end{array}$ & $\begin{array}{c}\text { Positive } \\
\text { Control } \boldsymbol{\mu g} / \mathbf{m l}\end{array}$ \\
\hline E. coli & $1.92 \pm 0.01$ & $2.13 \pm 0.01$ & $2.07 \pm 0.01$ & $3.8 \pm 0.01$ \\
$\boldsymbol{P}$. multocida & $1.83 \pm 0.05$ & $2.33 \pm 0.02$ & $2.54 \pm 0.03$ & $3.97 \pm 0.02$ \\
B. subtilis & $1.49 \pm 0.03$ & $2.15 \pm 0.02$ & $2.44 \pm 0.03$ & $3.72 \pm 0.01$ \\
S. aureus & $1.88 \pm 0.02$ & $1.37 \pm 0.01$ & $2.05 \pm 0.02$ & $3.73 \pm 0.01$ \\
\hline
\end{tabular}

\section{Table 7}

Minimum bactericidal concentration of $F$. cretica solvent fractions against selected bacterial strains

\begin{tabular}{|c|c|c|c|c|}
\hline Bacterial strains & $\begin{array}{c}\text { Benzene fraction } \\
\mu \mathrm{g} / \mathrm{ml}\end{array}$ & $\begin{array}{l}\text { Ethyl Acetate } \\
\text { fraction } \mu \mathrm{g} / \mathrm{ml}\end{array}$ & $\begin{array}{c}\text { Butanol fraction } \\
\mu \mathrm{g} / \mathrm{ml}\end{array}$ & $\begin{array}{c}\text { Positive Control } \\
\mu \mathrm{g} / \mathrm{ml}\end{array}$ \\
\hline E. coli & $2.07 \pm 0.02$ & $2.39 \pm 0.01$ & $2.06 \pm 0.01$ & $3.8 \pm 0.01$ \\
\hline P. multocida & $2.21 \pm 0.01$ & $2.29 \pm 0.01$ & $2.65 \pm 0.02$ & $3.97 \pm 0.02$ \\
\hline B. subtilis & $2.42 \pm 0.01$ & $1.54 \pm 0.01$ & $2.28 \pm 0.02$ & $3.72 \pm 0.01$ \\
\hline S. aureus & $1.97 \pm 0.01$ & $1.90 \pm 0.03$ & $1.23 \pm 0.01$ & $3.73 \pm 0.01$ \\
\hline
\end{tabular}

minimum inhibitory concentrations were observed as $1.49,2.15,2.44,2.42,1.54$ and $2.28 \mu \mathrm{g} / \mathrm{ml}$ for methanol, ethanol, acetone, benzene, ethyl acetate, and butanol fractions respectively. The positive control showed $3.72 \mu \mathrm{g} / \mathrm{ml}$ concentration to kill sufficiently B. subtilus strain. Butanol fraction showed minimum efficient concentration to kill B. subtilus strain followed by other fractions as; Butanol $<$ Acetone $<$ Butanol $<$ Ethanol $<$ Ethyl acetate $<$ Methanol 


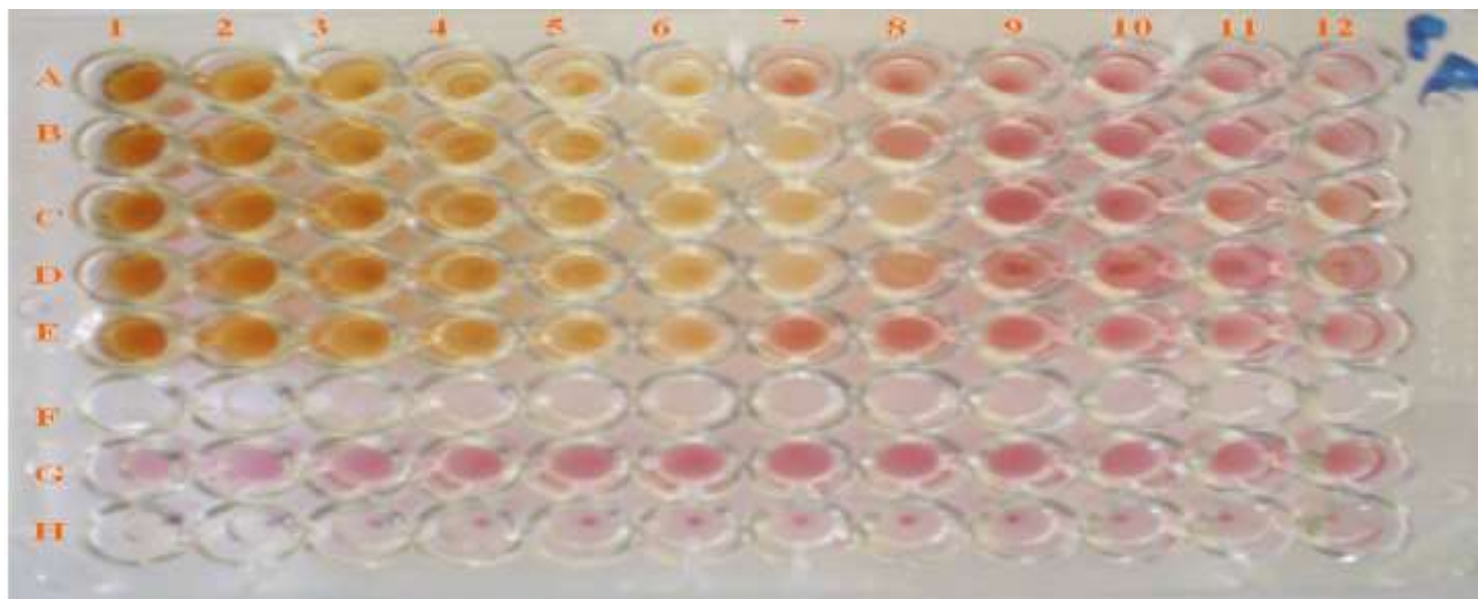

Fig. 7. The minimum bactericidal concentration of F. cretica extract fractions against E.coli

As shown in Table (6,7), the minimum inhibitory concentrations against $S$.aureus were found to be $1.88,1.37,2.05,1.97,1.90,1.23 \mu \mathrm{g} / \mathrm{ml}$. From results it was concluded that acetone fraction's minimum concentration can kill bacteria $S$. aureus more efficiently comparatively others as Acetone $<$ Ethyl acetate $<$ Benzene $<$ Methanol $<$ Ethanol $<$ Butanol (Fig.7)

\subsubsection{Minimum bactericidal concentration}

Minimum fungicidal concentration was determined by preparing dilutions of various solvent fractions of $F$. cretica by following standard protocols and procedures. The measured results are given in Tables (8\&9).

\section{Table 8}

Minimum fungicidal concentration of $F$. cretica solvent fractions against selected fungal strains

\begin{tabular}{ccccc}
\hline Fungal strains & $\begin{array}{c}\text { Methanol fraction } \\
\mu \mathrm{g} / \mathrm{ml}\end{array}$ & $\begin{array}{c}\text { Ethanol fraction } \\
\mu \mathrm{g} / \mathrm{ml}\end{array}$ & $\begin{array}{c}\text { Acetone fraction } \\
\mu \mathrm{g} / \mathrm{ml}\end{array}$ & $\begin{array}{c}\text { Positive Control } \\
\mu \mathrm{g} / \mathrm{ml}\end{array}$ \\
\hline A. niger & $2.60 \pm 0.01$ & $2.34 \pm 0.01$ & $2.33 \pm 0.02$ & $3.74 \pm 0.02$ \\
A. flavus & $2.245 \pm 0.05$ & $1.88 \pm 0.01$ & $1.92 \pm 0.02$ & $3.49 \pm 0.01$ \\
A. fusarium & $2.37 \pm 0.01$ & $2.60 \pm 0.03$ & $2.34 \pm 0.01$ & $3.38 \pm 0.01$ \\
F. Solani & $2.31 \pm 0.02$ & $2.52 \pm 0.03$ & $1.76 \pm 0.02$ & $3.52 \pm 0.01$ \\
\hline
\end{tabular}

Table 9

Minimum fungicidal

concentration of $F$. cretica solvent fractions against selected fungal strains

\begin{tabular}{ccccc}
\hline Fungal strains & $\begin{array}{c}\text { Benzene fraction } \\
\mu \mathrm{g} / \mathrm{ml}\end{array}$ & $\begin{array}{c}\text { Ethyl Acetate } \\
\text { fraction } \mu \mathrm{g} / \mathrm{ml}\end{array}$ & $\begin{array}{c}\text { Butanol fraction } \\
\mu \mathrm{g} / \mathrm{ml}\end{array}$ & $\begin{array}{c}\text { Positive Control } \\
\mu \mathrm{g} / \mathrm{ml}\end{array}$ \\
\hline A. niger & $2.33 \pm 0.01$ & $2.53 \pm 0.03$ & $2.23 \pm 0.01$ & $3.74 \pm 0.02$ \\
A. flavus & $1.82 \pm 0.02$ & $1.70 \pm 0.04$ & $2.13 \pm 0.03$ & $3.49 \pm 0.01$ \\
A. fusarium & $2.23 \pm 0.02$ & $2.62 \pm 0.02$ & $1.69 \pm 0.01$ & $3.38 \pm 0.01$
\end{tabular}




$\begin{array}{llllll}\text { F. solani } & 2.60 \pm 0.01 & 1.90 \pm 0.01 & 2.42 \pm 0.01 & 3.52 \pm 0.01 & \begin{array}{l}\text { From } \\ \text { results }\end{array} \text { given }\end{array}$

in Tables (8-9) it is concluded that against A.niger the minimum inhibitory concentration measured was $2.60,2.34$, $2.33,2.33,2.53$, and $2.23 \mu \mathrm{g} / \mathrm{ml}$ of methanol, ethanol, acetone, benzene, ethyl acetate, and butanol fractions respectively. The positive control showed $3.74 \mu \mathrm{g} / \mathrm{ml}$. Benzene showed minimum effective concentration to kill A. niger followed by Benzene $<$ Ethanol $<$ Butanol $<$ Methanol < Ethyl acetate <Acetone. against. flavus the minimum inhibitory concentrations of methanol, ethanol, acetone, benzene, ethyl acetate, and butanol fractions respectively were measured as $2.245,1.88,1.92,1.82,1.70$ and $2.213 \mu \mathrm{g} / \mathrm{ml}$. The positive control showed a $3.49 \mu \mathrm{g} / \mathrm{ml}$ concentration minimum to kill spores of A. niger. Butanol showed maximum efficiency to kill A. niger followed by other fractions as Butanol $<$ Ethanol $<$ Methanol $<$ Acetone $<$ Benzene $<$ Butanol. Against A. fusarium strain the minimum inhibitory concentrations of methanol, ethanol, acetone, benzene, ethyl acetate, and butanol fractions respectively measured were 2.37, 2.60, 2.34, 3.38, $2.23,2.62,1.69$, and $3.38 \mu \mathrm{g} / \mathrm{ml}$ respectively. The positive control showed a $3.72 \mu \mathrm{g} / \mathrm{ml}$ concentration to kill A. fusarium fungus. The order of efficiency of plant extract fractions can be written in ascending order as Butanol $<$ Acetone $<$ Butanol $<$ Ethanol $<$ Ethyl Acetate $<$ Methanol. Against $F$. solani the minimum inhibitory concentrations of methanol, ethanol, acetone, benzene, ethyl acetate, and butanol fractions were measured as 2.31,2.52,1.76,2.60,1.90 and $2.42 \mu \mathrm{g} / \mathrm{ml}$. Acetone extract fraction effectively killed $F$. solani with a minimum amount of concentration followed by Acetone $<$ Ethyl acetate $<$ Benzene $<$ Methanol $<$ Ethanol<Butanol (Anjum et al., 2013; Cho et al., 2010).

\section{Conclusion}

Recently, there has been an increasing trend towards the exploration of safer and effective antioxidants and antimicrobial functional ingredients from natural sources like fruits, vegetables, oilseed, cereals, grains and herbs. Plants have received much attention as sources of biologically active substances and considered as richest source of natural antioxidant and antimicrobial agents that includes various medicinally important compounds i.e. polyphenols, carotenoids and flavonoids etc. Therefore, the present analytical study was carried out in order in order to evaluate the phenolic profiling, partition fractionation and antimicrobial potential of contents of Fugonia extracts.

\section{Conflict of interest}

It is declared that there is no conflict of interest among the authors of this paper

\section{Acknowledgement}

Author is very thankful to Dean faculty of Science for providing funding to this project

\section{References}

1. Ahmed, T., \& Gilani, A. H. (2009). Inhibitory effect of curcuminoids on acetylcholinesterase activity and attenuation of scopolamine-induced amnesia may explain medicinal use of turmeric in Alzheimer's disease. Pharmacology Biochemistry and Behavior, 91(4), 554-559.

2. Anjum, F., Shahid, M., Bukhari, S. A., Anwar, S., \& Latif, S. (2013). Study of quality characteristics and efficacy of extraction solvent/technique on the antioxidant activity of bitter gourd seed. J Food Process Technol, 4(2).

3. Bainbridge, J. W., Smith, A. J., Barker, S. S., Robbie, S., Henderson, R., Balaggan, K., ... \& Petersen-Jones, S. (2008). Effect of gene therapy on visual function in Leber's congenital amaurosis. New England Journal of Medicine, 358(21), 2231-2239.

4. Chaovanalikit, A., \& Wrolstad, R. E. (2004). Total anthocyanins and total phenolics of fresh and processed cherries and their antioxidant properties. Journal of food science, 69(1), FCT67-FCT72.

5. Cho M, Kang I-J, Won M-H, Lee H-S and You S. (2010) The antioxidant properties of ethanol extracts and their solvent-partitioned fractions from various green seaweeds. Journal of medicinal food, 13, 1232-1239.

6. Čižmárová, L. (2015). History of and popular attitudes towards names for the czech-speaking territory. AUC Geographica, 50(1), 7-22.

7. Corless, C. L., Fletcher, J. A., \& Heinrich, M. C. (2004). Biology of gastrointestinal stromal tumors. Journal of Clinical Oncology, 22(18), 3813-3825. 
8. Eman, A. A. (2011). Morphological, phytochemical and biological screening on three Egyptian species of Fagonia. Acad Arena, 3, 18-27.

9. Fritsche, T. R., McDermott, P. F., Shryock, T. R., \& Walker, R. D. (2007). Agar dilution and disk diffusion susceptibility testing of Campylobacter spp. Journal of Clinical Microbiology, 45(8), 2758-2759.

10. Katewa, S. S., \& Galav, P. K. (2006). Additions to the traditional folk herbal medicines from Shekhawati region of Rajasthan.

11. Omale, J., \& Okafor, P. N. (2008). Comparative antioxidant capacity, membrane stabilization, polyphenol composition and cytotoxicity of the leaf and stem of Cissus multistriata. African Journal of Biotechnology, 7(17).

12. Patil, G. G., Mali, P. Y., \& Bhadane, V. V. (2008). Folk remedies used against respiratory disorders in Jalgaon district, Maharashtra.

13. Qureshi, H., Asif, S., Ahmed, H., Al-Kahtani, H. A., \& Hayat, K. (2016). Chemical composition and medicinal significance of Fagonia cretica: a review. Natural product research, 30(6), 625-639.

14. Raskin, P., Banuri, T., Gallopin, G., Gutman, P., Hammond, A., Kates, R., \& Swart, R. (2003). Great transition upheavals and transitions on the way to a planetary society. ISOE materials Social ecology, (20).

15. Sheahan, M. C., \& Chase, M. W. (2000). Phylogenetic relationships within Zygophyllaceae based on DNA sequences of three plastid regions, with special emphasis on Zygophylloideae. Systematic Botany, 371-384.

16. Steel, R. G. D., \& Torrie, J. H. (1960). Principles and procedures of statistics. Principles and procedures of statistics.

17. Sterilized, D. W. (2000). Toxic effect of various plant part extracts on the causal organism of typhoid fever. Current Science, 78(7), 780.

18. Yang, Z. Y., Yang, R. D., Li, F. S., \& Yu, K. B. (2000). Crystal structure and antitumor activity of some rare earth metal complexes with Schiff base. Polyhedron, 19(26-27), 2599-2604. 